\title{
Does the U.S. Constitution Need an Equal Rights Amendment?
}

\author{
Lisa Baldez, Lee Epstein, and Andrew D. Martin
}

\begin{abstract}
For over 3 decades, those engaged in the battle over the Equal Rights Amendment (ERA), along with many scholarly commentators, have argued that ratification of the amendment will lead U.S. courts (1) to elevate the standard of law they now use to adjudicate claims of sex discrimination, which, in turn, could lead them (2) to find in favor of parties claiming a denial of their rights. We investigate both possibilities via an examination of constitutional sex discrimination litigation in the 50 states-over a third of which have adopted ERAs. Employing methods especially developed for this investigation, we find no direct effect of the ERA on case outcomes. But we do identify an indirect effect: the presence of an ERA significantly increases the likelihood of a court applying a higher standard of law, which in turn significantly increases the likelihood of a decision favoring the equality claim.
\end{abstract}

Arbitrary gender lines still clutter the lawbooks and regulations of the nation and states, the Supreme Court vacillates insecurely from one decision to the next, and is sometimes disarmed from reaching any decision, as it holds back doctrinal development and awaits the signal the Equal Rights Amendment would supply. [Kay 2004, p. 18]

The leading recent example of ... [a] rejected yet ultimately triumphant [amendment] is the Equal Rights Amendment. . . . Today, it is difficult to identify any respect in which constitutional law is different from what it would have been

LISA BALDEZ is Associate Professor of Government at Dartmouth College, LEE EPSTEIN is the Edward Mallinckrodt Distinguished University Professor of Political Science and Professor of Law at Washington University, and ANDREW D. MARTIN is Associate Professor of Political Science at Washington University. We are grateful to the National Science Foundation, the Center for New Institutional Social Science, the Washington University School of Law, and the Weidenbaum Center on the Economy, Government, and Public

[Journal of Legal Studies, vol. 35 (January 2006)]

(C) 2006 by The University of Chicago. All rights reserved. 0047-2530/2006/3501-0009\$01.50 
if the ERA had been adopted. For the last quarter-century the Supreme Court has acted as if the Constitution contains a provision forbidding discrimination on the basis of gender. [Strauss 2001, pp. 1476-77]

At a time when women are "entering the workforce, running for political office, and seeking jobs once closed to them" in record numbers (Strauss 2001, p. 1505), does the American Constitution still need an Equal Rights Amendment (ERA)? Surely women's rights groups think so. Whether fueled by the successful use of state equal rights amendments in legal battles for same-sex marriage or by passage of the TwentySeventh Amendment in 1992-203 years after it was proposed-they have renewed their efforts to attain ratification of the amendment. Judging by the quotes above, however, the legal community is far less united over an answer. On the one side are Kay (2004) and the many others who argue that ratification of the ERA will clarify a particularly murky area of the law and, in the process, generate a nearly irreversible sea change in sex discrimination jurisprudence (Eskridge and Hunter 1997; Kaufman 2001). ${ }^{1}$ That sea change, on this account, could come about in one of two ways: directly, by prompting judges to take a more skeptical view of sex-based discrimination or, as is more typically argued, indirectly, by leading judges (1) to elevate the standard of law they now use to adjudicate claims of sex discrimination, which, in turn, could lead them (2) to find in favor of parties claiming a denial of their rights. Either way, to put the argument more concretely, with the amendment in place, courts would no longer uphold a wide range of sex-based classifications that are currently permissible, such as those that make it easier for children born out of wedlock overseas to become citizens if

Policy for supporting our research. We also owe thanks to faculty at Cal Tech, Rice University, St. Louis University, Stanford University, and Washington University (especially to participants in the Workshop on Empirical Research in the Law) and to Eric Posner and an anonymous referee for supplying many useful suggestions; to Susan Appleton, Jeffrey A. Segal, and Nancy Staudt for offering sage advice during the formative stages of this project; and to Scott Friedman, David Lewarchik, Shelby Johnston, Tasina Nitzschke Nihiser, and Peter Ryan for outstanding research assistance. We used R and Stata to conduct the analyses presented in this article. The project's Web site (http://epstein.wustl.edu/research/ERA.html) houses a full replication archive, including a database containing all the cases and variables we used in this study, as well as the documentation necessary to reproduce our results.

1. Commentary on the Equal Rights Amendment (ERA) also attaches importance to the symbolic value of the amendment (see, generally, Nussbaum 2000; Siegel 2001), but these days it is the practical consequences that scholars tend to stress and that we emphasize here as well. 
their mother, rather than their father, is a citizen (upheld by the U.S. Supreme Court in Tuan Anh Nguyen v. INS, 533 U.S. 53 [2001]), those that place restrictions on abortion funding (upheld in Harris v. McCrae, 448 U.S. 297 [1980]), and those that limit the military draft to men (upheld in Rostker v. Goldberg, 453 U.S. 57 [1981]). ${ }^{2}$

Momentarily we say more about these possible effects of a federal ERA. For now we only wish to emphasize that, however familiar the claims of its supporters, ${ }^{3}$ at least some scholars remain doubtful that the amendment could produce any effect, direct or otherwise. Mansbridge (1986) was among the first to express doubts about the ability of even a formal constitutional rule to eradicate the force of societal pressures and judicial ideology in the sex discrimination context; judges, she argued, would make their own determinations, either rejecting or embracing the ERA's ends. Strauss (2001) and others continue to make this general argument today, although decidedly operating under the assumption that courts have tended to choose the latter route. To these commentators, it is difficult to see the need for the ERA's instantiation in the Constitution because decisions of the U.S. Supreme Court have largely fulfilled the amendment's chief objectives. As for those objectives that remain unfulfilled, an ERA, they maintain, is unlikely to be of much added value given the flexibility courts enjoy in interpreting and applying legal standards (Case 2000; Estrich 2002; Sherwin 1984-85; Post 2003).

Which side has the better case? Is an ERA likely to be as momentous in effect as Kay predicts or little more than the constitutional redundancy that Strauss foresees? Frankly, no one knows, nor can they know with any degree of certainty: because the ERA is not yet a part of the federal Constitution, we cannot observe its effect on either standards of law or case outcomes. But we can make inferences about its impact by looking to the U.S. states (see Gammie 1989; Hirczy de Mino 1997; Linton 1997). That is because over one-third have incorporated ERAs into their constitutions-with many of those amendments containing similar lan-

2. For other examples, see Brake (1996); Daughtrey (2000); Eskridge and Hunter (1997); Freund (1971); Gammie (1989); Halberstam and Defeis (1994); Hirczy de Mino (1997); Hunter (2001); Kurland (1971).

3. Recall that altering the standard or rule used to adjudicate sex discrimination claims (that is, elevating sex to a "suspect" classification; see Section 2 of this article) was a primary motivation for the drive for (and against) the ERA in the 1970s (Brown et al. 1971; Dorsen and Ross 1971; Emerson 1971; Harvard Law Review 1970; Kay 1981, 1988; Kurland 1971; Minnesota Law Review 1973; Mezey 1992; Vollers 1974)—and it remains so today, into the 2000s (Eskridge and Hunter 1997; Farone 2000; Francis 2001; Hirczy de Mino 1997; Kaufman 2001; Kay 2004; Lukey and Smagula 2000). 
guage and purporting to carry objectives analogous to the federal ERA (see, for example, Crump 1973; Farone 2000). Hence, by examining the standards used and the outcomes produced in constitutional sex discrimination litigation in courts of last resort in states with and without sex equality provisions, we may be able to gain leverage on the potential effect (whether direct, indirect, or both) of a national ERA.

At the very least, this is the task we undertake in this article. Our basic results, so that there will be no mystery about them, are relatively straightforward. While we observe no direct effect of the ERA on case outcomes, we do find, just as Kay (2004) and others assert, an indirect effect: the presence of an ERA significantly increases the likelihood of a court applying a higher standard of law, which, in turn, significantly increases the likelihood of a decision favoring the equality claim. These basic findings, as our emphasis on "relatively" indicates, are not without their share of nuances. While ERAs do, in fact, affect the adjudication of constitutional sex discrimination cases, they are just one of several factors that explain judges' choices over standards of law and the outcomes that application of those standards produce.

We develop these findings in four steps. We begin with a brief discussion of claims about the effect of ERAs and flesh out the various challenges to them. Next, we spell out our procedures for assessing arguments about the importance (or lack thereof) of the amendmentprocedures that are attentive to the possible dependence between standards of law and outcomes as well as to other factors that may lead judges to adopt particular standards and to reach particular conclusions. We then describe the results yielded by these procedures and conclude with a discussion of their implications for policy debates over the ERA and, more broadly, for future empirical research on judicial decisions.

\section{COURTS, SEX DisCRIMINATION, AND THE EQUAL RIGHTS AMENDMENT}

Framed in its most general terms, Kay and other supporters of the ERA make an argument hardly lacking proponents in the legal academy: namely, formal and informal institutions-here, rules that structure judicial decisions-matter. In particular, some suggest that a formal constitutional provision, an ERA, will have a direct effect on the nation's judiciary: its very presence in the Constitution, the argument goes, will lead judges to be more skeptical of sex-based classifications and thus more willing to eradicate them. The great bulk of scholars, though, assert 
that its effect will be more indirect: an ERA, on this account, (1) will force judges, even those who oppose the amendment, to follow a different, higher standard (or rule) of law when adjudicating sex discrimination cases and that (2) following this higher standard will, in turn, lead to many more rulings in favor of litigants alleging discrimination.

This indirect or two-part argument about the effect of an ERA emanates from the way judges seem to analyze claims of discrimination under the Fourteenth Amendment's Equal Protection Clause. ${ }^{4}$ To assess whether government actions run afoul of the clause, judges traditionally (that is, through the 1970s) applied one of two standards. Under the traditional rational basis test, as Table 1 shows, courts presume the validity of whatever classification the government has made; it is up to the party challenging the law to establish that it is irrational. ${ }^{5}$ Since this burden is difficult to meet, many commentators argue that the rational basis standard leads to a predictable outcome: courts defer to the government, generally upholding its classification (see, for example, Brown et al. 1971; Epstein and Walker 2004; Kaufman 2001; Mezey 2003).

Until the 1970s, the vast majority of claims of discrimination proceeded under the rules of this traditional rational basis test-with one particularly relevant exception: race. In light of the history surrounding ratification of the Fourteenth Amendment, the Supreme Court has held that classifications based on race should be subject to a less surmountable standard, known as strict scrutiny (or suspect class). Under this standard, judges presume that a government action is suspect or unconstitutional; only by showing that the law is the least restrictive means available to achieve a compelling state interest can the government overcome that presumption (see Table 1). Given the difficulty of making this showing, the conventional view among scholars is that application of the strictscrutiny test (apart from the affirmative action context) leads to outcomes just as predictable as those under the rational basis test-only, of course, in the opposite direction: when courts apply this stricter test, they almost always rule in favor of the party alleging discrimination. Or, as Gunther $(1971$, p. 8$)$ once famously put it, the suspect class test is "strict' in theory and fatal in fact," whereas the traditional rational

4. The Equal Protection Clause of the Fourteenth Amendment is restricted to the states; the governing constitutional provision for claims of discrimination against the federal government is the Due Process Clause of the Fifth Amendment. For the purposes of our discussion on sex discrimination, the two clauses are interchangeable.

5. We adapt the discussion in this section from Epstein and Walker (2004, pp. 652-54). 
248 / THE JOURNAL OF LEGAL STUdies / VOLUME 35 (1) / JANUARY 2006

Table 1. Equal Protection Tests

\begin{tabular}{|c|c|c|}
\hline Test & $\begin{array}{l}\text { Example of } \\
\text { Application }\end{array}$ & Validity Standard \\
\hline Rational basis & Age discrimination & $\begin{array}{l}\text { The law must be a reasonable } \\
\text { measure designed to achieve a } \\
\text { legitimate government purpose }\end{array}$ \\
\hline Intermediate scrutiny & Sex discrimination & $\begin{array}{l}\text { The law must be substantially } \\
\text { related to the achievement of an } \\
\text { important objective }\end{array}$ \\
\hline Strict scrutiny & Race discrimination & $\begin{array}{l}\text { The law must be the least restrictive } \\
\text { means available to achieve a } \\
\text { compelling state interest }\end{array}$ \\
\hline
\end{tabular}

Data source. Epstein and Walker (2004, p. 645).

basis standard provides "minimal scrutiny in theory and virtually none in fact." ${ }^{\circ}$

It is thus no wonder that as part of their effort to eradicate discrimination, women's rights groups, beginning in the late 1960s, attempted to convince courts that sex-based classifications ought to be subject to strict scrutiny rather than to a rational basis analysis (see, for example, Daughtrey 2000). Their litigation efforts did not succeed, but neither did they wholly fail. In response to their claims, the U.S. Supreme Court in 1976 articulated a new standard-often called intermediate or heightened scrutiny-that falls somewhere in between rational basis and strict scrutiny. Under it, the challenged law must be substantially related to the achievement of an important government objective (see Table 1). ${ }^{7}$

To be sure, many argue that application of intermediate scrutiny leads to more favorable outcomes for parties alleging gender discrimination than did the traditional standard (for example, Case 2000; Goldstein 1994). At the same time, though, they suggest that the intermediate

6. Justice O'Connor has taken issue with this claim, asserting that strict scrutiny is not always "strict in theory, but fatal in fact" (Adarand Constructors v. Peña [515 U.S. 200]). This is true with regard to affirmative action programs, but for all other race-based classifications, most contemporary commentators suggest that Gunther's assertion remains apt (Epstein and Walker 2004; Farber, Eskridge, and Frickey 2003; Mezey 2003). When it comes to sex-based classifications, however, some aver that O'Connor's view may have considerable merit. For more on this point, see note 9 .

7. Some justices have pushed for a variation on this approach that would require an "exceedingly persuasive justification" to sustain a sex-based classification (see Justice Ginsburg's opinion for the Court in United States v. Virginia [518 U.S. 15]). However, in light of recent Court decisions, such as Nguyen v. INS (533 U.S. 53), that effort has apparently failed (Bowsher 1998; Stobaugh 2002; Weinrib 2003). 
approach, as opposed to rational basis or strict scrutiny, produces far less predictable results: the Court may more often than not void sexbased classifications, but it more than occasionally upholds them (see, for example, Brake 1996; Kay 2004; Mezey 2003). Data derived from the United States Supreme Court Judicial Database (Spaeth 1999) showing that the party alleging sex discrimination prevailed in just slightly more than a majority of the 23 post-1976 suits (60 percent) tend to support this belief, as do doctrinal analyses of Court decisions. In United States v. Virginia (518 U.S. 515 [1996]), the federal government invited the justices to apply strict scrutiny to sex-based classifications-an invitation that many scholars (for example, Dorf 2002; Sunstein 1996), along with Justice Scalia, say the majority nearly accepted when it attempted to ratchet up the intermediate-scrutiny standard to strike down Virginia Military Institute's all-male admissions policy. Just 5 years later, in Nguyen v. INS (533 U.S. 53), however, the Court upheld a federal law that privileges a mother over a father in citizenship proceedings. While the majority proclaimed that the sex-based classification created by the law achieved important government interests and, as such, passed the heightened scrutiny test, Justice O'Connor disagreed. In a vigorous dissent, she accused the Court of explaining and applying "heightened scrutiny [in a] manner [that] is a stranger to our precedents" (533 U.S. at 74). "No one," she wrote, "should mistake the majority's analysis for a careful application of this Court's equal protection jurisprudence concerning sex-based classifications. Today's decision instead represents a deviation from a line of cases in which we have vigilantly applied heightened scrutiny to such classifications to determine whether a constitutional violation has occurred. I trust that the depth and vitality of these precedents will ensure that today's error remains an aberration" (533 U.S. at 97). In short, O‘Connor "not so subtly implied that the majority had, in effect, not applied intermediate scrutiny, but rational basis review" (Deutsch 2003, p. 187).

And therein lies the rub: without an ERA, according to many commentators, the justices will continue to invoke (or perhaps ignore) the murky intermediate rule, upholding or voiding classifications as they see fit, and judges on state and lower federal courts will do the same or even concoct their own approaches to sex discrimination (see, for example, Brake 1996; Francis 2001; Kay 2004; Mezey 2003). But with an ERA, jurists will be forced (1) to elevate sex to a suspect class, which in turn will lead them (2) to eradicate virtually all sex-based classifications (that is, not just 60 percent), as they now do in the case of race. 
This last sentence encapsulates what we have called an indirect (or two-part) claim about the ERA's effect-and it is certainly not one lacking in support or plausibility. Scores of scholarly analyses point to its merit (see, for example, Brown et al. 1971; Dorsen and Ross 1971; Emerson 1971; Eskridge and Hunter 1997; Farone 2000; Ginsburg 1978, 1979; Harvard Law Review 1970; Kaufman 2001; Kay 1981, 1988, 2004; Lukey and Smagula 2000; Minnesota Law Review 1973; Vollers 1974), friends and foes of the ERA alike post it on their Web sites (see, for example, Eagle Forum 2004; National Council of Women's Organizations 2004), the history of race discrimination litigation portends it (see, for example, Farber, Eskridge, and Frickey 2003; Greenberg 1976), and even U.S. Supreme Court justices have suggested as much; indeed, in the early 1970s, several declined to elevate sex to a suspect class at least in part because they thought it "inappropriate to 'amend' the Constitution while the ERA was pending" (Eskridge and Hunter 1997, p. 78; see also Ginsburg 1978, 1979).

Even so, as we noted at the outset, claims about the effect of an ERA, whether direct or indirect, are hardly without their share of critics. Strauss (2001, p. 1459) has famously argued that because they typically serve to "ratify changes that have already taken place in society," most successful (and unsuccessful) constitutional amendments are "irrelevant"; they will have neither direct or indirect effects on society. Then there are those commentators who take square aim at the ERA, alleging that even specific claims about its indirect effect may be misguided. One set, for example, asserts that the amendment's presence would not necessarily ensure adoption of strict scrutiny and that its absence does not automatically negate it (Brake 1996; Denning and Vile 2000; Gammie 1989; Kaufman 2001; O’Neill 1993; Sherwin 1984-85). In support, they point to federal courts that have all but ignored the current intermediate standard and have instead invoked higher or lower rules as they so desire; they also point to state courts of last resort that have used the intermediate or even rational basis standard to adjudicate sex discrimination cases even if their constitution contains an ERA, as well as to supreme courts that invoke strict scrutiny in the absence of an ERA. ${ }^{8}$ Many more

8. Of course, federal courts are supposed to adhere to legal principles established by the U.S. Supreme Court, and state courts are supposed to view federal law as establishing a floor (although not a ceiling) on civil rights and liberties below which they cannot go. But as the numerous studies we cite in the text-not to mention our own reading of the cases-indicate, these norms do not always hold, at least not in this area of the law. Even the U.S. Supreme Court occasionally departs from its own standard to adjudicate sex discrimination cases (see Mezey 2003). 
commentators, though, aver that, even if the ERA prompted courts to apply strict scrutiny, it would make little difference in how they treat sex-based classification. Leading the way here is Mansbridge (1986, pp. 50-51), who argues that the ERA "would almost certainly have made sex at least a 'suspect' classification" but that "treating sex merely as a 'suspect' classification would [leave judges] free to strike down any statute involving sex discrimination that did not in their view have a compelling justification, while leaving them free to uphold any statute that they thought did have compelling justification" (see also Case 2000; Mezey 2003; Schoen 1978; Sherwin 1984-85; Stanford Law Review 1950; Tarr and Porter 1982). ${ }^{9}$

What these analyses underscore, to frame their critiques more broadly, is an argument advanced in study after study of judicial decisions; namely, while institutions-whether formal (such as constitutional dictates) or informal (such as legal principles)—may matter, they are not as determinative of outcomes as claims about the ERA's effects make them out to be. Indeed, the extant social science literature on judging typically defines institutions as sets of rules that structure interactions (see, for example, Epstein and Knight 1998; Murphy 1964), not as rules that establish outcomes, and it typically views the choices judges make as a function of many other forces, including the judges' own political preferences and personal attributes, features of the external environment in which they deliberate, and the characteristics of the particular suits they must resolve (see, for example, Caldeira, Wright, and Zorn 1999; Cross and Tiller 1998; George and Epstein 1992; Gryski, Main, and Dixon 1986; Pinello 2003; Revesz 1997; Segal, Cameron, and Songer 1995).

In emphasizing this point, we do not mean to suggest that the social science literature dismisses rules altogether. While a number of individual scholars may subscribe to this view (or, at the very least, do not build institutions into their decision-making models), many others do notas exemplified by studies arguing that particular types of institutions for selecting judges may be more likely than others to induce sophisticated judicial behavior (for example, Bright and Keenan 1995; Burbank and Barry 2002; Tabarrok and Helland 1999) and those explaining why formal constitutional dictates and the norm favoring respect for prec-

9. These (largely doctrinal) analyses indicate that (1) courts applying the same standard to assess the same sex-based classification at roughly the same point in time do not always reach the same conclusion and that (2) courts applying rational basis do not always uphold sex-based classifications and courts applying suspect scrutiny do not always strike them. 
edent may serve to constrain judges, even those who prefer different rules (for example, Caminker 1994; Knight and Epstein 1996; see also Richards and Kritzer 2002). What we do mean to suggest, rather, is that in none of these studies, or in any others we can identify, are the authors contending (in contrast to ERA supporters) that institutions determine outcomes in all circumstances and in all matters. In fact, a central message in the extant literature on judging (see especially George and Epstein 1992; Pinello 2003; Segal, Cameron, and Songer 1995) and the basic point of Mansbridge's (1986) analysis of the potential effect of an ERA is that rules may constrain courts, but they do not-as so much commentary on the amendment seems to maintain-mechanically lead them to make particular choices; many other factors may come into play.

\section{DATA AND RESEARCH METHODS}

These sorts of critiques, coupled with the lack of empirical scrutiny, underscore the importance of assessing assertions about the impact of the ERA. While there may be good reasons to believe that ERAs will generate outcomes more favorable to parties alleging discrimination either directly or by structuring the standards that judges employ to adjudicate such disputes, there are equally good reasons to question that belief. At the very least, these claims strike us and others as asking too much of formal and informal rules. While rules certainly can serve to structure choices, it seems imprudent to believe that they do all the work-especially when so many studies of judging suggest otherwise.

Of course, we can assess these various perspectives empirically. As we noted at the outset, an investigation into the standards used and outcomes produced in constitutional sex discrimination cases in the nation's 50 state courts of last resort ${ }^{10}$ - those operating in legal environments with and without an ERA-should permit us to draw inferences about the validity of direct and indirect claims. So too such an investigation ought to facilitate assessments of the arguments of some, that an ERA will produce no effect on courts; of others, that it will not necessarily lead to the application of strict scrutiny; and of yet a third group, that application of strict scrutiny will not necessarily lead to predictable, pro-equality outcomes; that rather in all instances other

10. For ease of explication, we use the terms "state court of last resort" and "state supreme court" interchangeably even though we recognize that some state courts of last resort are not named "supreme court." 
factors play a crucial role explaining judicial choices. To be sure, our assessment of these claims, as well as any inferences we may draw about the effect of an ERA, will be of a higher (that is, more certain) quality for the context we can observe-the states-than for the one we cannot observe-the federal level. Nonetheless, in light of the methodological tack we take, which entails controlling for many factors relevant to state and federal judging, not to mention the similar language and purposes of the state and national amendments, we should be able to gain some leverage on the potential effect(s) of a national ERA.

It is to this methodological approach that we now turn. In what directly follows, we describe the procedures we used to gather data on our unit of analysis (constitutional sex discrimination cases), the variables we incorporated into our statistical model, and the method we employed to estimate the model. Sections 3 and 4 detail the results yielded by these procedures.

\subsection{The Unit of Analysis: Constitutional Sex Discrimination Cases}

To assess the possible effects of an ERA, we set out to collect data on all constitutional sex discrimination cases resolved in state courts of last resort between 1960 and 1999. ${ }^{11}$ This proved a challenging task. No equivalent of Spaeth's (2005) United States Supreme Court Judicial Database exists for state supreme courts, and searches of electronic resources (such as LEXIS or Westlaw) are unlikely to produce all the relevant suits.

In light of these obstacles, scholars investigating state court decisions have developed their case lists from multiple sources. In amassing his database on gay rights litigation, for example, Pinello (2003) conducted computer-aided searches and drew on scholarly writings on the subject. We generally followed suit. In our quest to uncover all constitutional sex discrimination cases, we too performed various LEXIS searches and systematically extracted cases from extant literature on the subject. ${ }^{12}$ Heeding the lessons of research by Gryski, Main, and Dixon (1986),

11. We settled on this time frame for reasons practical (the existence, as we explain later in the text, of valid and reliable measures of judicial preferences), analytical (a sufficient time line pre- and postratification of most state ERAs), and jurisprudential (an ample period since the instantiation of contemporary equal protection doctrine).

12. The project's Web site provides the details of these searches, including the terms we entered into LEXIS, to identify the cases and the literature (http://epstein.wustl.edu/ research/ERA.html). 
however, we supplemented these sources by "shepardizing" the U.S. Supreme Court's major constitutional sex discrimination cases. ${ }^{13}$

After perusing each opinion unearthed by these various proceduresmainly to ensure that the court in question was the state court of last resort, that the dispute was real and not hypothetical, and that, in the course of resolving the suit, the state justices addressed a claim of constitutional sex discrimination ${ }^{14}$-we were left with 416 cases. ${ }^{15}$ Of course, we cannot say that we identified each and every pertinent case, but like Pinello (2003), we do not believe we missed many. We also can say that our procedures are reproducible, replicable, and capable of being updated and backdated.

\subsection{Variables Incorporated into the Analysis}

With the 416 cases in hand, we set out to collect the information necessary to animate the three primary variables of interest: (1) the presence or absence of an ERA, (2) the standards courts use to adjudicate sex discrimination claims, and (3) case outcomes. We also amassed data designed to assess the various factors suggested by previous studies of judging that may affect the standard used, the case outcome, or both. We elaborate on these below.

\subsubsection{Variables of Primary Interest: An Equal Rights Amendment, the Stan-} dard of Law, and the Outcome. The direct claim about the ERA's effect is straightforward enough: the presence of an ERA should lead courts to reach decisions in favor of parties alleging discrimination. The linchpin of the indirect (or two-part) claim also is the presence (or absence) of an ERA, but standards intervene: it is an ERA, under the indirect claim, that necessitates the use of a higher standard of law, but it is the

13. Shepard's enables researchers to identify all cases citing to a particular case. A list of the 13 court cases we shepardized is available on our Web site.

14. Specifically, we excluded courts in the District of Columbia and Puerto Rico and eliminated the handful of advisory opinions produced by our searches because not all state courts have the authority to issue these sorts of opinions. In light of the purpose of our project, an additional criterion was that the court invoked a standard of law (see Table 1) to adjudicate the sex-based claim. Since we return to this point later (see Section 2.2.1), suffice it to note here that in secondary analyses designed to assess the robustness of our results, we incorporated those cases in which the court failed to apply a standard (by adding the variable zero to the Standard variable; see Section 2.2.1). The results, which are housed on our Web site, were remarkably stable and consistent with those depicted in Tables 2 and 3 (see Sections 3 and 4).

15. The project's Web site houses a full replication archive, including a database containing all the cases and variables we used in this study and the documentation necessary to reproduce our results. 
application of a higher standard of law that generates an outcome favorable to the party alleging discrimination. To put it another way, in the first part of this two-part claim, the ERA is the key causal variable and the standard is the dependent variable; in the second part, the standard serves as the key causal variable, and the outcome, the dependent variable.

Measuring the first independent variable of the indirect claim (and the only one of interest in the direct claim), the presence of an ERA, is a relatively straightforward task, requiring us to do little more than determine whether an ERA was in effect (coded as one) ${ }^{16}$ or not (coded as zero) at the time the court resolved the case. ${ }^{17}$

Turning next to the standard of law, which serves as both a dependent and an independent variable in assessing the indirect claim, we code each into one of the three categories depicted in Table 1: 1, rational basis (minimal scrutiny); 2, intermediate (heightened) scrutiny; or 3, strict scrutiny (suspect class). ${ }^{18}$ Since our replication archive houses a detailed coding instrument, suffice it to mention here the primary problem we encountered: cases in which we could not identify a standard because either the court simply did not apply or articulate one or because it explicitly refused to select among various alternatives. We exclude these cases from our primary analysis (that is, they are not among the 416), but we include them $(N=51)$ in supplemental investigations designed to assess the robustness of our results.

Finally, investigating both direct and indirect claims requires information about the outcome of the litigation. Here we take the approach commended by Gryski, Main, and Dixon (1986), among others, and code whether the party alleging sex discrimination won (equal to one) or lost (equal to zero) the dispute. ${ }^{19}$

16. A list of the 18 ERA states along with the date and exact wording of their sex equality provisions is available on our Web site.

17. As our emphasis on "relatively" indicates, we encountered several (fairly minor) problems in coding this variable. We describe these on the project's Web site, as well as the steps we took to account for them in our analyses.

18. The project's Web site houses our coding rules, along with the results of our reliability analysis on the coding of this variable.

19. We are well aware of normative debates among some feminists about whether, as Goldstein (1994, p. 209) puts it, "to argue for protective legislation for women on the grounds that without such legislation women are unfairly disadvantaged by making them play by rules that were designed with men in mind, and that are ill-adapted to women's biology and life patterns." While we appreciate this argument, our coding scheme remains relatively agnostic over it (for example, if a pregnant woman fired from her job is the plaintiff in a suit alleging sex-based discrimination in violation of her constitutional rights, 
2.2.2. Other Factors Influencing Judicial Decisions. These three variables-(1) the presence or absence of an ERA, (2) the standards courts apply to sex discrimination claims, and (3) case outcomes-provide us with the information essential to scrutinize claims about the ERA's possible effects. What we lack are the data necessary to assess challenges to those claims or, for that matter, any argument that emphasizes the utter determinacy of rules. Examining such challenges requires us to attend to the other forces that come to bear on judging-specifically, those that may influence the two dependent variables of our study, the standard of law and the case outcome. From a close reading of the literature, as we allude above, emerge two sets of factors relevant to the choice of standard: features of the state supreme court and of the external sociolegal environment in which it operates. Some of the same factors also may shape the outcomes of the disputes but, to account fully for them, we also must consider an additional set: specific characteristics of sex discrimination suits.

Beginning with features of the court, existing research emphasizes two. One is the political preference of the majority of its members, as structured by the institutions used to select them. This last clause is crucial, for, again as we noted earlier, many analysts argue that particular types of selection systems are more likely than others to induce sophisticated behavior on the part of actors-such that the greater the accountability established in the institution, the higher the opportunity costs for judges to act sincerely, and, accordingly, the more extensive sophisticated behavior will be (for example, Bright and Keenan 1995; Burbank and Friedman 2002; Hall 1987). On this account, then, the decisions of elected judges will be more in line with popular sentiment, and those of appointed judges more on track with the preferences of the governmental regime (see, for example, Croly 1995; Dahl 1957; Gryski, Main, and Dixon 1986; Pinello 1995; Tabarrok and Helland 1999). Standard partisan-based measures of the judicial preferences-

she would be the party alleging sex discrimination). We also understand the position of some scholars that a formal rule, such as an ERA, will not effectively end the subordination of women by men at least in part because of the "problem of male dominance in virtually all facets of social, political, and economic life" (MacKinnon 1987, p. 762; see also Becker 1989; Case 2002). To be sure, we do not attempt to assess this position, but our analysis does lend support to the claims of Sullivan (2002) and others who argue that formal equality provisions are not always inefficacious but rather that their effectiveness depends a good deal on who is interpreting them. Specifically, to foreshadow our results, we find that as the fraction of women serving on a state supreme court increases, the likelihood of the court adopting a higher standard of law also increases—and significantly increases at that. 
such as the proportion of Democrats on the bench-are thus inappropriate for this reason and for another unique to our study: during the years under analysis here, the political parties switched positions on the ERA (Wolbrecht 2000), thereby making any proxy of preferences that relies primarily on partisanship (including party-adjusted ideology scores; see Langer 2004) even more dubious for our purposes. But there is one measure that nicely fits our needs: the government and citizen ideology scores Berry et al. (1998) developed and assigned to each state for each year between 1960 and 1999. ${ }^{20}$ Operating under an assumption common in many studies-that we can assess the preferences of state justices on the basis of the ideology of the citizenry (if they are elected via partisan or nonpartisan ballots) and on the basis of the government (if they are appointed)—we assigned a Berry et al. score to each case in the database, depending on the selection system in effect at the time the court resolved the dispute. Given the way Berry and his colleagues computed the scores (with higher numbers representing higher degrees of liberalism), we expect a positive relationship between the scores and standards: the higher the score (that is, the more liberal the court), the more likely it is to apply a higher standard of review; we also anticipate that liberal courts will reach more equality-oriented outcomes.

A second feature of the court worthy of inclusion centers on the presence of women justices. Virtually from the day Sherry (1986) penned her classic work on the possibility of a feminine jurisprudence, scholars have hotly debated whether female judges "speak in a different voice" (for recent reviews of this literature, see, for example, Epstein and Mather 2003; Kay and Sparrow 2001; Schneider 2001). While the results of various research projects exploring judicial votes are decidedly mixed, those centering on jurisprudence-especially in the area of sex discrimination-are clearer. A consensus now exists that women have "pushed the law forward in sex discrimination cases" (Kay and Sparrow 2001, p. 11), with their distinct approach to legal principles possibly altering the choices made by their male colleagues (Sherry 1986; Sullivan 2002).

20. Berry et al. (1998) report scores for the period 1960-93. We used the updated and revised scores (through 1999) ("revised 1960-1999 government/citizen ideology series") that Berry and his colleagues deposited with the Inter-university Consortium for Political and Social Research (Study No. 128). By necessity, partisanship is a factor-albeit one among many-that figures into the government measure. 
On the basis of this consensus, ${ }^{21}$ we think it reasonable to hypothesize that the greater the fraction of female justices on the court, the greater the probability of the adoption of a higher standard of law. ${ }^{22}$

These variables relate to features of the court; a second set pertains to the sociolegal environment in which the court operates. A relevant factor along these lines is whether an intermediate appellate court existed at the time the court decided the case (coded one if it existed and zero otherwise). Scholars include this variable in almost all models of state court decisions out of the belief that appellate tribunals "siphon off routine cases" (Gryski, Main, and Dixon 1986, p. 145), leaving the more serious matters for courts of last resort to resolve. In the context of our study, the presence of these courts thus should increase the likelihood of the court applying a higher standard of review, as well as finding in favor of the party alleging discrimination, "since frivolous appeals will be screened by the intermediate appellate courts, and the high courts will be evaluating only the more serious claims of sex discrimination" (Gryski, Main, and Dixon 1986, p. 145; see also Atkins and Glick 1976; Canon and Jaros 1970).

A second variable centering on the sociolegal environment is the state's level of enthusiasm for the national ERA, which we also can capture with a simple dichotomous variable: whether the state ratified the federal amendment (equal to one) or not (equal to zero). Because this may provide important information to the justices about the public's receptivity to the application of a higher standard of law to resolve sex discrimination cases, it may very well exert an influence on that choice quite apart from the presence (or, more pointedly, absence) of a state ERA. At the very least, ratification of the federal ERA could send state justices precisely the opposite signal that the failure to ratify sent to their federal counterparts; namely, they would not be usurping their state's political process if they elevated sex to a suspect class (Eskridge and Hunter 1997; Ginsburg 1978). Accordingly, we expect justices operating

21. Note that because this consensus is over jurisprudence and not votes, our hypothesis pertains to standards and not outcomes. We did, however, assess whether the fraction of female justices affects outcomes. As it turns out, the variable produces a positive but insignificant coefficient-although it in no way affects the basic findings reported in Table 3.

22. Allen and Wall (1993) contains data on women serving on state courts of last resort between 1922 and 1992; we updated this information from various sources, including court Web sites. 
in states that ratified the national ERA to apply a higher standard of review.

As our discussion so far suggests, we foresee that various features of the courts and of the environment in which they operate will affect both the standards they apply and the outcomes they reach. There is yet a third set that we anticipate will influence only the latter: characteristics of the litigation. The general idea here is that even if the justices adopt a particular standard of law to adjudicate sex discrimination claims, they will apply it to reach different outcomes depending on the features of the case (see, for example, Beck and Baker 1993; Mansbridge 1986; McCausland 1983; Mezey 2003; Simpson 1977).

Operating under this logic, we combed the extant normative and doctrinal literature to identify relevant characteristics of the litigation that may affect case outcomes. Three emerged in virtually every analysis: whether or not (1) the government defended a sex-based classification, (2) the government or another party defended the classification on the basis of a relevant physical difference between men and women, and (3) a woman claimed discrimination. Our expectation about the government's involvement is simple enough: when, as a party or an amicus curiae, it defends a sex-based classification, we expect the likelihood of defeat for the litigant alleging a violation of his or her rights to increase. This hypothesis reflects a voluminous literature in both the federal and state judicial contexts demonstrating that courts defer to the government-especially in criminal cases (see, for example, Atkins and Glick 1976; Emmert 1992; Glick and Vines 1973; Gryski, Main, and Dixon 1986; Traut and Emmert 1998; Wheeler et al. 1987; Yale Law Journal 1978). For our purposes, we simply incorporate a variable indicating government involvement (coded as one) or not (coded as zero), but we also, in a supplementary analysis, control for the type of suit (criminal or civil).

With regard to the second case characteristic, scholars are virtually unanimous in their belief that a defense of discrimination on the basis of a relevant physical difference makes it more difficult for both federal and state courts to resolve the dispute in favor of the party alleging discrimination-regardless of the standard of law they use (see, for example, Epstein and Walker 2004; Kay 1981; Mezey 2003). Hirczy de Mino's (1997) doctrinal analysis of the Texas high-court decisions, for example, finds that even when the justices apply an elevated standard, they tend to rule against the equality claim in litigation involving a physical difference (he specifically points to toplessness). Mezey (2003) 
and many others make a similar point about federal jurists, explaining that some have downright asserted that courts ought apply a different standard when such differences arise. The resulting hypothesis, then, is straightforward: if a defense based on a relevant physical distinction arises in the litigation (coded one if yes and zero if no), we anticipate that the justices will find against the party alleging discrimination.

Far less straightforward is the role of women litigants in increasing or decreasing the probability of success for the party alleging inequity. In perhaps the most systematic analysis of litigation in this area, Gryski, Main, and Dixon (1986) found that state tribunals are more sympathetic to claims of discrimination made by females than by males, and Mezey (2003) has suggested much the same of the U.S. Supreme Court. Given the perceived purpose of an ERA, these results might not seem particularly surprising, but some observers have balked. Various feminist legal scholars, for example, have argued that the male-dominated judiciary manipulates seemingly equally oriented principles to reach outcomes that further the interests of its "own kind" ${ }^{23}$ and doctrinal analyses of cases in Texas and Pennsylvania, two states with an ERA, suggest the plausibility of this view (Hirczy de Mino 1997; Beck and Baker 1993). These conflicting findings make hypothesizing difficult; yet in light of the more systematic evidence marshaled in the Gryski, Main, and Dixon (1986) and Mezey (2003) studies, we expect the probability of success for the party alleging discrimination to increase when that party is a female (coded one; coded zero if not a female).

\subsection{Statistical Models and Estimation Methods}

As we have just outlined it, our analysis is aimed at assessing both direct and indirect claims about the ERA's impact. In terms of the former, we expect six factors to affect case outcome: an ERA, of course, and then the preferences of the court, the existence of an intermediate appellate court, a female as the equality party, a claim of a physical difference between men and women, and the government as a defender of the sexbased classification. As for the indirect account, we incorporate four variables, in addition to the presence of an ERA, to account for the standard of law applied by the court (the preferences of the court, national ERA ratification, the proportion of the court composed of women, and the existence of an intermediate appellate court), and five, in addition to the standard of law (but not the ERA), to account for the

23. See note 19 . 
outcome (once again, the preferences of the court, the existence of an intermediate appellate court, a female as the equality party, a claim of a physical difference between men and women, and the government as a defender of the sex-based classification). Since Appendix A provides a summary of these variables, we need only mention here that, given our coding scheme, we expect all the variables to be positively related to the standard of law. We also expect all but two (a claim of a physical difference between men and women and the government as a defender of the sex-based classification) to be positively related to case outcome; for those two, we anticipate a negative relationship. ${ }^{24}$

Assessing these expectations as they pertain to the direct account is hardly problematic: we can simply regress the outcome of the litigation (for or against the party alleging discrimination) on the six variables of interest to determine the ERA's impact on judging. Investigating the more indirect (or two-part) account, however, presents a technical challenge of no small proportions: because we aim to explore the assumption that the choice of standard and the outcome are dependent, we must analyze two equations, with two differentially measured dependent variables-standard of law (an ordinal variable) and outcome (a dichotomous variable) -in one model. Since no standard statistical model will adequately perform this task, we developed one: a bivariate mixedresponse probit model, which allows for correlation across two equations and which we estimate using the maximum likelihood method.

Appendix B provides the details of this statistical model, along with our estimation methods. What is important here is that even though the parameter estimates resulting from these procedures admit to an interpretation akin to probit coefficients, our methodological approach is distinctive in two regards. First, it enables us to estimate parameters that-while substantively similar to those that would result from analyzing decisions over standards of law and case outcomes independently-are more efficient because we employ all the data to obtain them. Second, the approach facilitates a more exacting investigation of the dependence between the choices of standard and outcome (that is, the dependence assumed by the indirect, two-part claim) because we are able to obtain a precise estimate of that dependence (in the form of an estimate of a correlation parameter, $\rho$ ) as a result of our ability to control

24. These represent the variables in (and concomitant expectations of) our primary analyses. As we have noted throughout, we consider variations in an effort to assess the robustness of our results. See Section 4 for the details. 
for the factors that may affect both the standard and outcome in one model.

\section{THE DIRECT EFFECT OF EQUAL RIGHTS AMENDMENTS}

As we have implied throughout, most scholars writing in the sex discrimination area have argued that the ERA's effect will come primarily, if not exclusively, through its impact on legal standards. Assertions that the ERA's mere presence in the Constitution will be sufficient to prompt judges to eradicate sex discrimination do, to be sure, appear in the literature, but they are, relative to indirect accounts, few and far between.

Our results suggest that they should remain sparse. As we can see in Table 2, while all but one of the control variables produce statistically significant coefficients (in the hypothesized direction), the ERA does not.

And further interrogation of the data does little to change this basic result. So, for example, a model that incorporates the standard of law invoked by the court, along with all the other variables depicted in Table 2 , also returns a statistically insignificant coefficient on the ERA variable. The same holds for each and every analysis we conducted, including models that take into account variables we expect to affect legal standards (rather than outcome) (see Table 3), such as state ratification of the federal ERA and the proportion of female judges on the bench. ${ }^{25}$

\section{THE INDIRECT EFFECT OF EQUAL RIGHTS AMENDMENTS}

These supplemental analyses, not to mention the results depicted in Table 2, show that the mere presence of an ERA in a constitution has little impact on judges' decisions: no direct effect, in other words, emerges. Quite a different conclusion obtains when we turn to indirect effects. In fact, estimating the bivariate mixed-response probit model leads to results that are quite striking: all the variables, as we can see in Table 3 , produce statistically significant coefficients, and in the expected direction. The $\rho$ estimate, which indicated the correlation between the standard of law used and the outcome reached, also attains statistical significance.

25. In addition to these attempts to verify the results displayed in Table 2, we also considered other factors (including the possibility of endogeneity) that might have affected the estimates given our use of observational data. See note 28 for more details. 
Table 2. Maximum Likelihood Estimates for a Probit Model Fit to the State Constitutional Sex Discrimination Data

\begin{tabular}{lcc}
\hline Variable & $\begin{array}{c}\text { Maximum } \\
\text { Likelihood } \\
\text { Estimate }\end{array}$ & $\begin{array}{c}\text { Standard } \\
\text { Error }\end{array}$ \\
\hline ERA & .158 & .142 \\
Judicial Ideology & .017 & $.004^{*}$ \\
Intermediate Appellate Court & .359 & $.158^{*}$ \\
Physical Difference & -.721 & $.171^{*}$ \\
Government Opposition & -.856 & $.138^{*}$ \\
Female & .273 & .148 \\
Constant & -.715 & $.233^{*}$ \\
\hline
\end{tabular}

Note. $N=416 ; \ln L=-236.8399$. The dependent variable is the outcome (for or against the party alleging sex discrimination).

* Statistically significant at the $\alpha=.05$ level.

Taken collectively, these basic results lend support to claims about an indirect effect of the ERA-but not without important caveats. In what follows we explore those caveats, which emerge from an examination of the substantive impact of our findings. But two points deserve emphasis before we proceed further. The first is that while Table 3 reflects our primary thinking about the impact of state ERAs, a sufficient number of concerns about our measures and specification-many of which we raised in Section 2-led us to undertake a full-fledged assessment of the robustness of our principal results. ${ }^{26}$ Our Web site contains a reckoning of this assessment, but the main point here is that it leads to no changes in the interpretation we offer below: in none of these alternative specifications did the parameter estimates for the ERA and $\rho$ fail to reach statistical significance.

A second point also relates to the integrity of the results displayed in Table 3 but centers on a potential problem caused by our data (rather than our measures)-specifically, that they cluster by court and time. While an insufficient amount of data exist to model extra court or time

26. So, for example, we incorporated the 51 cases in which the court did not articulate a standard and added the value of zero to the Standard variable to account for these cases, redefined value one of the ERA variable to include only states ratifying their amendment in the 1970s, included a variable to differentiate criminal and civil cases, and added the variable representing the proportion of women to the outcome equation-to name just a few of the checks we conducted (see our Web site for others). As we note in the text, the results were remarkably stable and consistent with those depicted in Table 3-with one notable exception: although including the proportion-of-women variable does not alter any of the other results in Table 3, it fails to significantly affect case outcomes. 
264 / THE JOURNAL OF LEGAL STUdies / VOLUME 35 (1) / JANUARY 2006

Table 3. Maximum Likelihood Estimates and (Asymptotic) Standard Errors for the Bivariate Mixed-Response Probit Model Fit to the State Constitutional Sex Discrimination Data

\begin{tabular}{lcc}
\hline & $\begin{array}{c}\text { Maximum } \\
\text { Likelihood } \\
\text { Estimate }\end{array}$ & $\begin{array}{c}\text { Standard } \\
\text { Error }\end{array}$ \\
\hline$\beta_{1}$ Parameter & & \\
Constant & -1.106 & $.189^{*}$ \\
ERA & .460 & $.120^{*}$ \\
Judicial Ideology & .011 & $.004^{*}$ \\
ERA Ratification & .456 & $.143^{*}$ \\
Proportion Women & 2.187 & $.566^{*}$ \\
Intermediate Appellate Court & .354 & $.138^{*}$ \\
$\tau_{1}$ : Cut Point & 1.179 & $.084^{*}$ \\
$\beta_{2}$ : Constant & & \\
Judicial Ideology & -.794 & $.225^{*}$ \\
Intermediate Appellate Court & .017 & $.004^{*}$ \\
Physical Difference & .376 & $.153^{*}$ \\
Government Opposition & -.685 & $.160^{*}$ \\
Female & -.725 & $.130^{*}$ \\
$\rho$ : Correlation & .376 & $.138^{*}$ \\
\hline
\end{tabular}

Note. $N=416 ; \ln L=-593.0884$. The dependent variable in equation (1) $\left(\beta_{1}\right.$ variables) is standard of law; the dependent variable in equation (2) $\left(\beta_{2}\right.$ variables) is outcome; $\rho$ represents the correlation between the two equations.

* Statistically significant at the $\alpha=.05$ level.

dependence, we went to some length to ensure that our inferences were not unduly affected by possible clustering. Specifically, we recomputed our standard errors (clustering by court, decision year, and court within decision year) using the White (1980) sandwich estimator, which generates standard errors that remain consistent even in the face of unmodeled dependence due to clustering. ${ }^{27}$ When we invoke these standard errors, rather than the asymptotic ones reported above, the results do not change markedly $;^{28}$ most important, the key variables of interest (an ERA and the standard of law) are not affected whatsoever. Accordingly,

27. See Appendix B for details; the robust standard errors are included in the replication archive on our Web site.

28. Specifically, when clustering by year, all coefficients remain statistically significant; when clustering by court, the Intermediate Appellate Court variable becomes insignificant in the standard equation; when clustering by court within year, the Government Opposition and Female variables become insignificant in the outcome equation. 
for the substantive interpretation to follow in Section 4.1, we rely on the regular (asymptotic) standard errors. ${ }^{29}$

\subsection{The Indirect (Two-Part) Claim}

Our diagnostic work noted, let us turn to a deeper consideration of the results, beginning with the prevailing wisdom encapsulated in the indirect claim about an ERA's effect. As to the first part of the claim, the findings generally are supportive, but not without their share of nuances. On the one hand, as we can observe in Table 3 that the coefficient produced by the ERA variable is positive and significant, which indicates that the presence of such a formal equality provision does in fact increase the probability of the adoption of a higher standard of law. So too, as we can see in Figure 1, that statistical finding is not without substantive import. What the figure shows is that the probability, over the 30 -year period, of the application of a higher standard of law varies considerably depending on whether the state adopted an ERA: when we set all other variables at their mean, the likelihood, on average, of a court invoking strict scrutiny to adjudicate a sex-based claim is just .11 in the absence of an ERA. That probability doubles in the presence of an ERA, to .23. On the other hand, because the figure of .23 is relatively distant from 1.00 , it is far from certain that an ERA will lead to the automatic application of strict scrutiny. The presence of an ERA may raise the probability of courts taking that step, but it does not-just as some

29. In addition to the concerns we just outlined, we considered three others that might contaminate the results given our use of observational data. First, there would be endogeneity — which could bias our parameter estimates-if standards of law (or case outcomes) caused states to ratify their ERAs or caused states to be more liberal. But in light of accounts stressing the critical role played by social movements and state party politics (and ideology) in the enactment of ERAs, this does not appear to be the case (see, for example, Gammie 1989; Hirczy de Mino 1997; Soule and Olzak 2004). The second possible contaminating factor is caused by nonrandom selection: it is possible that litigants may shop for venues, launching litigation only in "friendly" states (that is, those with ERAs). If this were the case, our estimate of the effect of ERAs would be biased against finding a significant effect. (If litigants shopped for venues perfectly, they would initiate cases in states with ERAs, so the presence or absence of an ERA would have no significant effect.) The bias would run in the wrong direction (toward finding a significant effect) only in the unlikely event that litigants shop for venues in unfriendly states. Finally, we might be concerned about possible collinearity if two of the explanatory variables (the ERA and ideology) are tightly coupled, thereby rendering it impossible to disentangle the independent effects of both. But this is not the case: the two variables correlate at only .085. Moreover, even if they were correlated at much higher levels, the model would still supply the right answer, except that the standard errors would be larger because the model would be less certain as to whether to blame the ERA or the ideology for the outcome. 


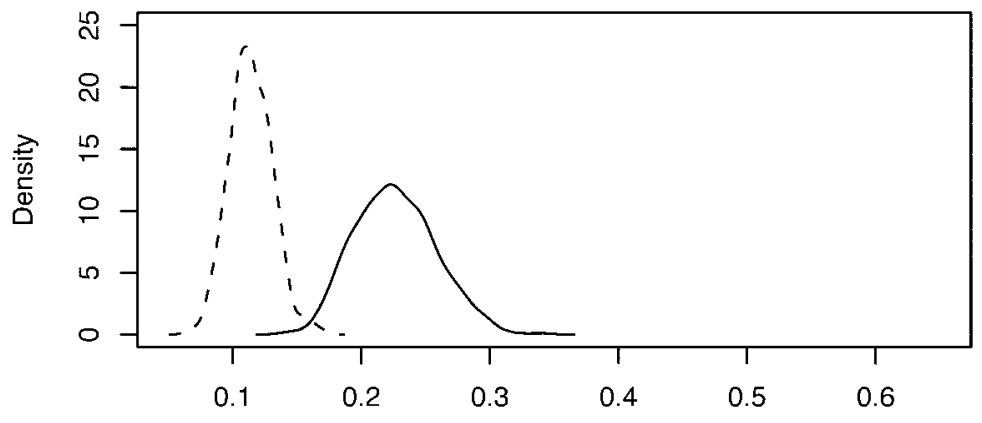

Probability of Strict Scrutinty Standard

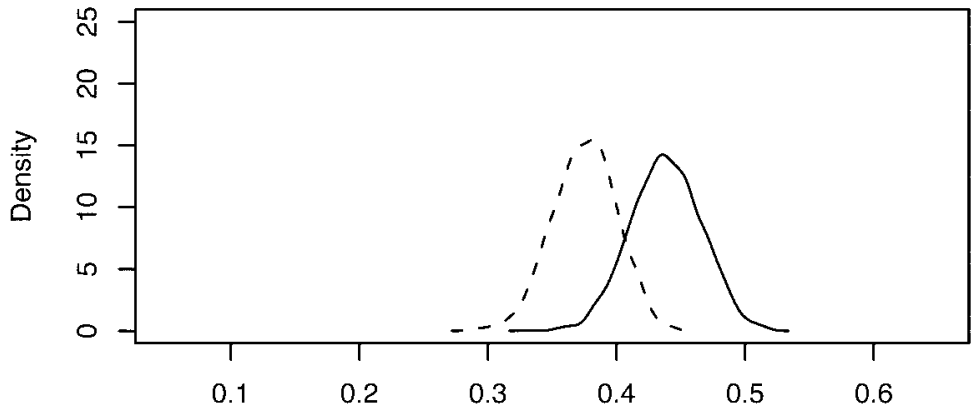

Probability of Intermediate Scrutinty Standard

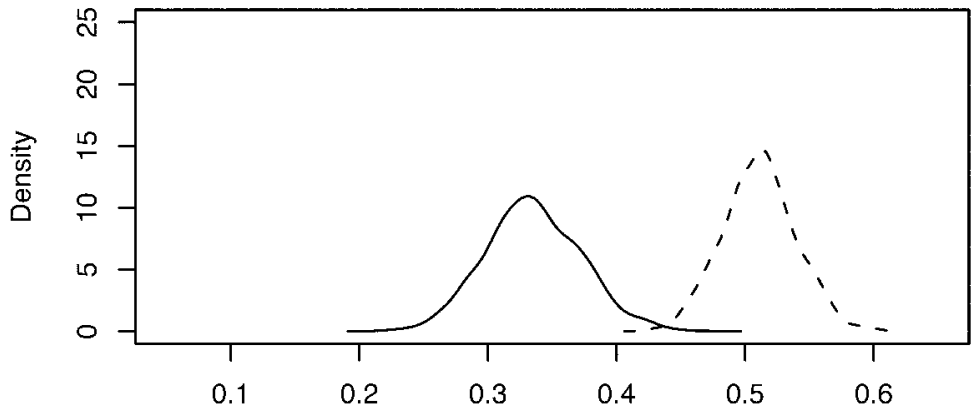

Probability of Rational Basis Standard

Figure 1. Effect of the presence or absence of a state equal rights amendment on standards of law. The curves represent the probability density of a court invoking strict scrutiny (top), intermediate scrutiny (middle), or rational basis (bottom) accounting for parameter uncertainty. The dashed curves represent states without an ERA; the solid curves are those with an ERA. All other variables are held fixed at their sample means. We generated these figures using a CLARIFY-like simulation (see King, Tomz, and Wittenberg 2000). 


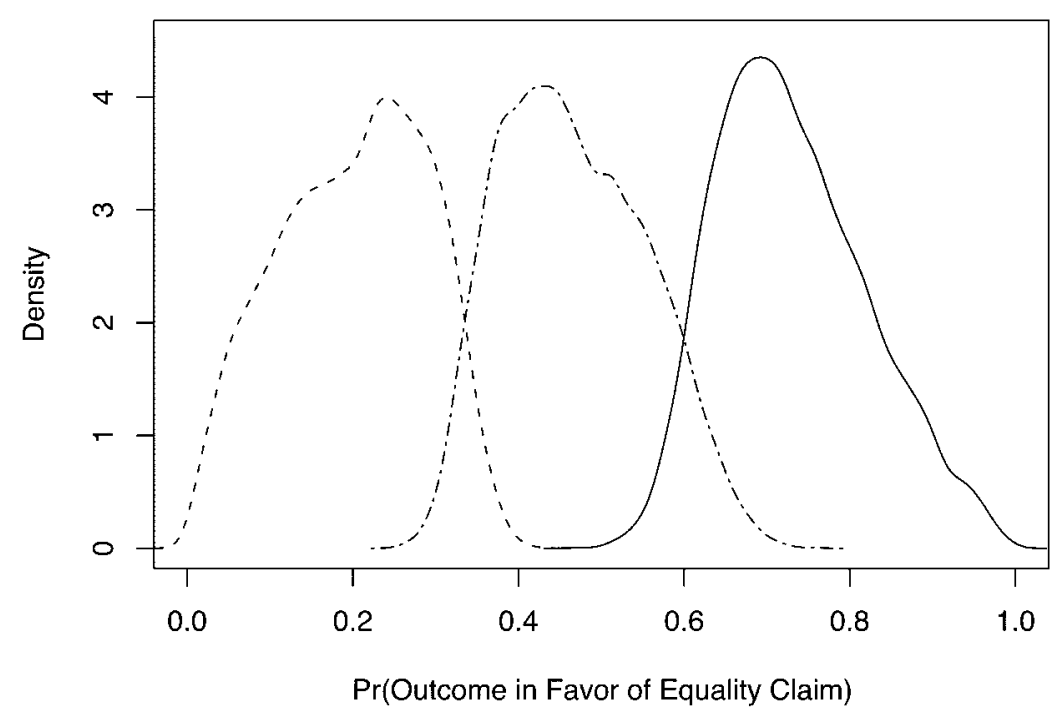

Figure 2. Effect of standard of law on case outcomes. The curves represent the probability density of a court reaching an outcome favoring the litigant alleging sex discrimination when it applies the rational basis standard (dashed curve), the intermediate standard (dot-dashed curve), and the strict scrutiny standard (solid curve), accounting for parameter uncertainty. We constructed the figure from the simulation outlined in Appendix B. All covariates are held at their sample means.

scholars have contended and as more general work on judicial decisions would suggest-ensure it.

If the results pertaining to the first part of the indirect claim are somewhat mixed, those on the second part are far cleaner and stronger. The $\rho$ coefficient in Table 3 indicates that the standard a court uses and the outcome it reaches are significantly correlated, and the probabilities displayed in Figure 2 reveal that the relationship is substantively meaningful as well. Notice the monotonic increase in those odds, such that when courts assess sex classifications via a rational basis test-the lowest level of scrutiny - the likelihood of finding in favor of the equality claim is just .20. That probability increases to .47 when courts apply intermediate scrutiny and to .73 when they invoke strict scrutiny. In other words, and in line with the bulk of the extant literature, under mid-level scrutiny litigants alleging sex discrimination are nearly as likely to win as they are to lose, while application of the lowest and highest standards leads to rather predictable outcomes-although in opposing directions: 
under a rational basis standard, claims of sex discrimination will, on average, fail, and under strict scrutiny they will, in all likelihood, prevail.

\subsection{Features of the Court, the Environment, and the Cases}

With the notable exception of those arguing against any effect of an ERA whatsover, it would hardly be a stretch to read our results as providing further ammunition to all those engaged in the debate over the amendment-friends and foes alike-as well as to many of the scholars who have commented on the amendment's likely impact. But neither they nor we should ignore the full lessons of our modeling exercise: namely, the presence (or absence) of a formal constitutional provision is not the only variable exerting an influence on the choice of standard, and the use of a high (or low) standard of law is not alone in accounting for case outcomes.

Turning first to the decision of what standard of law to apply, Table 3 shows that all the incorporated variables play some role in explaining that choice. The fraction of women on the bench holds particularly impressive explanatory power. As that fraction increases, as Figure 3 illustrates, the probability of applying a higher standard of law soars, even after controlling for the presence of an ERA. To see the magnitude of the effect, consider a court composed exclusively of male justices. On average, the odds of that court using a rational basis standard, setting all other variables at their mean, is a hefty .50; the probability of that same court applying strict scrutiny is but .12 . Now consider a court nearly equally divided between male and female judges: as the figure illustrates, the probabilities nearly reverse: the odds of this court applying rational basis are (on average) but .14, while the probability for strict scrutiny jumps to 47 .

This finding lends empirical support to the writings of Sherry (1986) and others on the existence of a feminine jurisprudence. While women may not speak in a different voice in all legal areas, nor consistently vote differently from men, their presence on the bench seems to exert an influence on how their colleagues structure the adjudication of sexbased claims. Similarly interesting is the importance of the sex of the equality-oriented litigant in explaining case outcomes. As we can observe in Table 3, this variable attains statistical significance, and it too has a meaningful influence on who ultimately prevails in the suit. If we set all other variables at their sample mean, the probability of the court finding discrimination is nearly .50 when a woman brings the suit; it dips to about a third for all other litigants. In light of the history of ERAs, not 

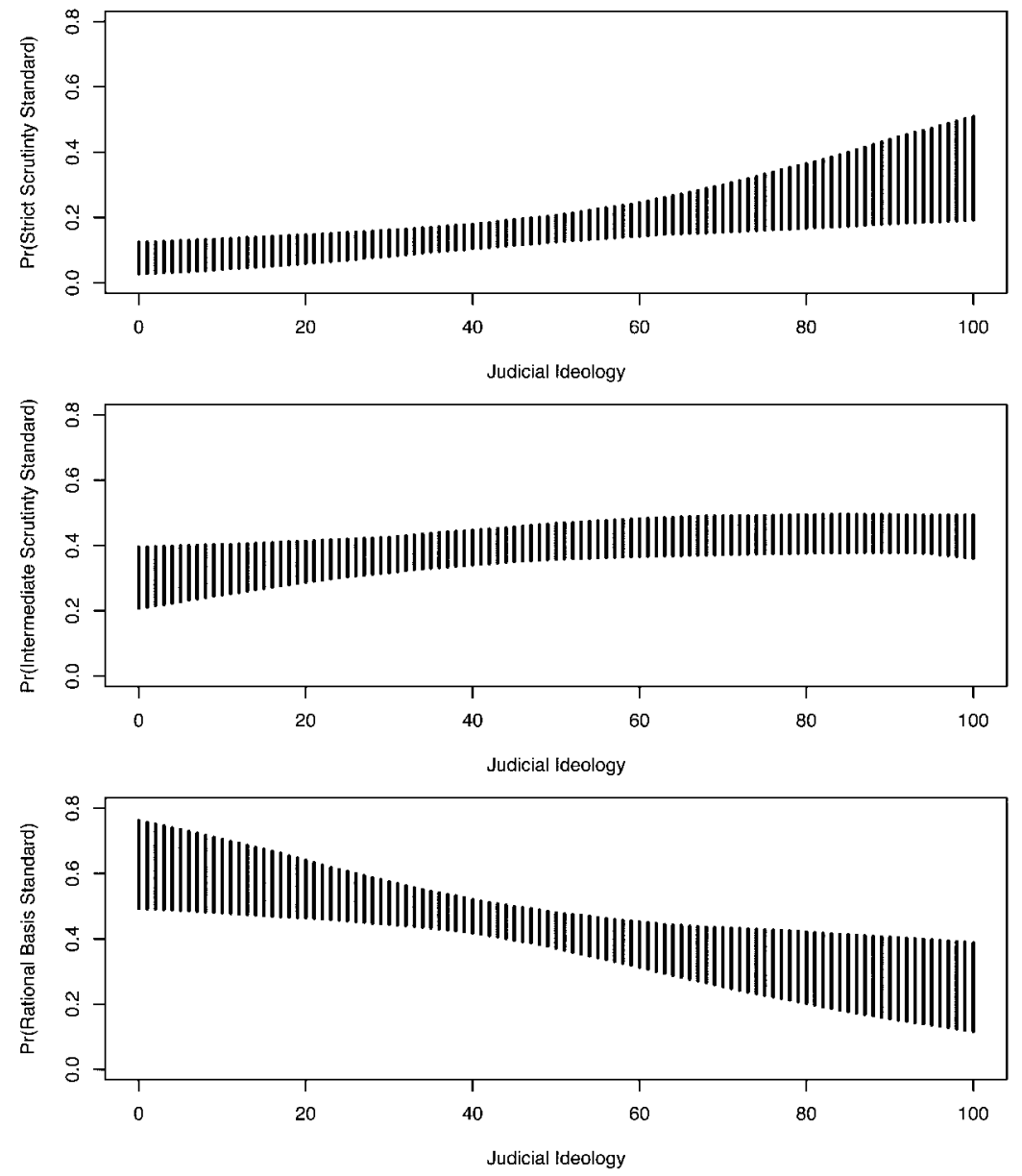

Figure 3. Effect of the proportion of women on the bench on standard of law. The panels illustrate the predicted probabilities of a court adopting strict scrutiny (top), intermediate scrutiny (middle), and rational basis (bottom) as the proportion of women on the court increases, accounting for parameter uncertainty. The vertical lines represent 95 percent confidence intervals. All other variables are held fixed at their sample means. We computed these using a CLARIFY-like simulation (see King, Tomz, and Wittenberg 2000). 


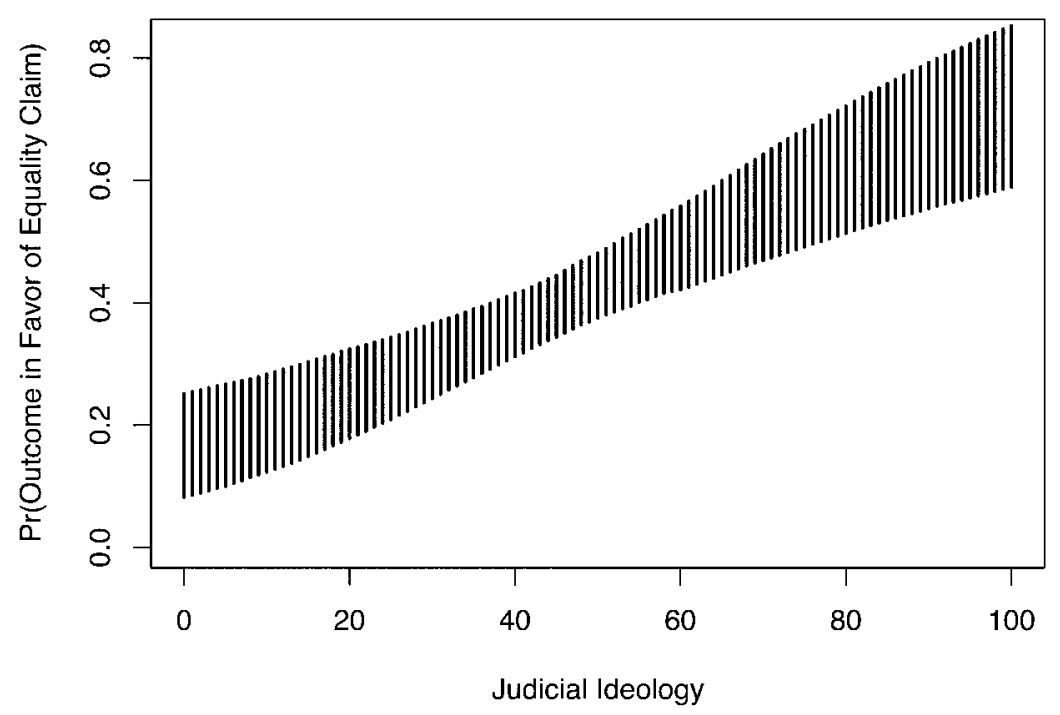

Figure 4. Effect of judicial ideology on case outcome, illustrating the predicted probability of an outcome favoring the litigant alleging sex discrimination over the range of the Judicial Ideology variable (from least to most liberal), accounting for parameter uncertainty. The vertical lines represent 95 percent confidence intervals. All other variables are held fixed at their sample means. We computed this figure using a CLARIFY-like simulation (see King, Tomz, and Wittenberg 2000).

to mention the findings of empirically based studies exploring the outcomes of sex discrimination litigation (see, for example, Gryski, Main, and Dixon 1986; Mezey 2003), this finding is hardly a surprise; yet it does present something of a challenge to (largely) normative scholarship arguing that men have been the largest beneficiaries of equality provisions.

Finally, notice the role played by the political preferences of the judges-in terms of both accounting for the standard of law applied and the outcome reached. The variable reaches statistical significance in both equations (see Table 3): as the judges' preferences move from right to left of center, the odds of applying a higher standard and of reaching a decision in favor of the litigant claiming discrimination increase. Figure 4 substantiates this point with regard to case outcomes: the probability of an outcome favoring the equality claim jumps from .15 to .74 as courts move from extreme conservatism to extreme liberalism and when we hold all other variables at their means. 
Indeed, the effect of ideology (along with the proportion of females on the court, the sex of the litigant, and so on) is so dramatic that we might question the relative substantive importance of the two key variables of interest here-the presence or absence of an ERA and the standard of law. How likely is it, in other words, that courts will apply the highest legal standard to adjudicate sex discrimination claims in the absence of an ERA but in the presence of other relevant explanatory factors?

As it turns out, the effect of an ERA is hard, although not impossible, to minimize. To see this, consider a court that is extremely liberal (100 on the Berry et al. [1998] measure) and that has the highest proportion of female judges in our sample (about .50). If that court operates in a state without an ERA, the probability of it adopting strict scrutiny is fairly high, .64; in the presence of an ERA, the likelihood increases, although certainly not precipitously, to .79 . Interesting too is that the .79 probability drops rather dramatically-to well below .64-if either the proportion of females or the court's liberalism dips to or below mean levels. So, for example, even if a court in a state with an ERA is composed of about half females, the probability of it adopting strict scrutiny drops to .59 (from .79) should it be composed of ideological moderates (that is, a court at the ideological mean). The comparable figure for the same court in a non-ERA state is .40 .

What these various scenarios show is that, under the right circumstances (say, an extremely liberal court with an unusually high proportion of women), the lack of an ERA will not necessarily stand as a barrier to the adoption of strict scrutiny. That is why we say it is not impossible to minimize an ERA's effect. But it is also why we say it is difficult to do so: the right circumstances are far from the normal circumstances (they are instead the extreme and unusual circumstances). And, even when they do occur, they never generate probabilities of the adoption of strict scrutiny that are higher than those obtained in states with ERAs. Under every possible scenario (for example, setting both ideology and the proportion of women at their means, setting ideology at the lowest level and women at the highest, and so on), courts in states with an ERA are more likely to adopt strict scrutiny than those operating in states lacking the amendment. ${ }^{30}$

30. These probabilities are available on our Web site. 
272 / THE JOURNAL OF LEGAL STUdies / VOLUME 35 (1) / JANUARY 2006

5. DISCUSSION: DOES THE U.S. CONSTITUTION NEED AN EQUAL RIGHTS AMENDMENT?

In the title of this article, we ask a straightforward question: does the U.S. Constitution need an ERA? With our analyses now complete, we can supply an equally straightforward answer: if we believe that it is desirable for courts to produce a larger number of equality-oriented outcomes, then an ERA is neither an impediment nor a constitutional redundancy. Quite the opposite: while ERAs do not have a direct effect on judicial decisions, they do, even after controlling for other relevant factors, increase the probability of a court applying a higher standard of law to adjudicate claims of sex discrimination. And the application of a higher standard of law, even after controlling for other relevant factors, increases the probability of a court reaching a disposition favorable to litigants alleging a violation of their rights.

At the same time, though, our study suggests that an ERA will not be the constitutional panacea (or Pandora's box) some make it out to be. While the results lend support to arguments suggesting that these formal constitutional provisions probably will alter the way courts adjudicate claims of discrimination, our findings also demonstrate that other factors-from the fraction of women composing the court to the position taken by the government over the suit's resolution to the facts it entails-likely will impact the efficacy (or lack thereof) of an ERA.

These represent the basic policy implications of our research, but they are in fact, as our use of "probably" and "likely" indicates, qualified implications. That is because we have been able to assess systematically the quality and certainty of our results only with regard to the effect of ERAs in the states. We cannot-in the absence of an amendment to the U.S. Constitution and resulting litigation-make a similar assessment about the federal context. Nonetheless, for reasons we have already mentioned, we believe that our analyses provide some insights into the potential effect of a federal ERA-insights that, in general, lend support to Mansbridge's (1986) reasoned speculation of some 20 years ago: even if passage of the ERA leads federal jurists to adopt a strict-scrutiny approach to sex-based classifications, a step rather likely under our analysis, that approach will not necessarily compel them to strike down all classifications as is generally the case in race litigation. ${ }^{31}$ Rather, and again as Mansbridge and others (for example, Case 2000; Mezey 2003;

31. As we indicated in note 6 , affirmative action litigation is a notable exception. 
Sullivan 2002; Strauss 2001) astutely recognized, the outcomes of sex discrimination suits will depend, at least in some part, on the types of judges interpreting the constitutional provision and the particular facts of the suit itself.

If this is the primary policy implication of our study, then the primary contribution for more general analyses of legal decisions is clear: just as so many judicial specialists have suggested, we cannot and should not count on rules and principles of law to do all the work in explaining the choices judges make; comprehensive accounts require a consideration of a range of forces. At the same time, though, we cannot and should not discount institutions, whether formal or informal in nature. To be sure, as we emphasized earlier, few students of courts and law think in this way: at least in theory, most believe that rules play an important role in adjudication. But theory occasionally turns out to be different than practice, as exemplified by the many papers-and recent ones at that-that omit rules from their analyses of court decisions.

Our study suggests that this omission is not optimal. At minimum, failure to incorporate institutions amounts to underspecification; at most, it serves to perpetuate a myth about judging common in the social science literature (and becoming increasingly so in empirical legal scholarship): that it is a phenomenon largely about politics and not law. The lesson of our study, as well as of other contemporary analyses, is that judging is about both, and only by characterizing it as such are analysts likely to develop more apt descriptions and richer explanations of how jurists operate. 
274 / THE JOURNAL OF LEGAL STUdiES / VOLUME 35 (1) / JANUARY 2006

APPENDIX A

Table A1. Description of the Variables $(N=416)$

\begin{tabular}{lrccc}
\hline Variable & Mean & $\begin{array}{c}\text { Standard } \\
\text { Deviation }\end{array}$ & Minimum & Maximum \\
\hline State ERA & .35 & .48 & 0 & 1 \\
Court Preferences & 44.05 & 18.88 & .96 & 92.36 \\
ERA Ratification & .47 & .50 & 0 & 1 \\
Female Justices & .06 & 1.00 & 0 & .43 \\
Appellate Court & .74 & .44 & 0 & 1 \\
Standard of Law & 1.72 & .75 & 1 & 3 \\
Physical Difference & .23 & .42 & 0 & 1 \\
Government Participation & .63 & .48 & 0 & 1 \\
Female Litigant & .29 & .46 & 0 & 1 \\
Outcome & .41 & .49 & 0 & 1 \\
\hline
\end{tabular}

\section{APPENDIX B: A BIVARIATE MIXED-RESPONSE PROBIT MODEL}

We are interested in modeling two dependent variables that we observe at the same time. The first variable of interest is called Standard, and the second is called Outcome. We do not assume that these choices are independent, and thus do not fit two separate models. Rather, we explicitly model the dependence with a bivariate mixed-response probit model that allows for correlation across two equations.

Here is the notation to be used throughout:

$i=1, \ldots, N$ indexes the cases;

$y_{1, i}=$ the Standard chosen in each case; this is an ordinal variable that can take values $1,2, \ldots, K$; in our application $K=3$;

$x_{1, i}=$ a column vector of covariates that explains the Standard chosen on the case; it is of dimensionality $\left(P_{1} \times 1\right)$;

$y_{2, i}=$ the Outcome reached in each case; this is a dichotomous variable that takes a value of one if the party alleging discrimination won the case and zero otherwise; and

$x_{2, i}=$ a column vector of covariates that explain the Outcome reached in the case; it is of dimensionality $\left(P_{2} \times 1\right)$.

The model we estimate is essentially an ordinal probit model (McKelvey and Zavoina 1975) and a dichotomous probit model with correlated errors. ${ }^{32}$ We

32. This particular application is a special case of a bivariate ordinal probit model. The model is easily extended to allow for continuous outcomes and any number of equations. However, if one were to move beyond two dependent variables, inference using the maximum likelihood method would become essentially impossible. This is the same problem that plagues estimation of multinomial probit models. Performing Bayesian inference, using 
assume that our observed dependent variables $y_{1, i}$ and $y_{2, i}$ are governed by latent (unobserved) utilities in the standard fashion, denoted $z_{1, i}^{*}$ and $z_{2, i}^{*}$, which are modeled by the covariates $x_{1, i}$ and $x_{2, i}$.

The first equation is the model for Standard, which is an ordinal variable taking values $1,2, \ldots, K$. We assume that

$$
z_{1, i}^{*}=x_{1, i}^{\prime} \beta_{1}+\varepsilon_{1, i}
$$

where $\beta_{1}$ is a $\left(P_{1} \times 1\right)$ column vector of parameters to estimate. The probability that $y_{1, i}$ takes particular values is determined by the distributional assumption, the $\beta_{1}$ parameters, and a set of cut points $\tau_{0}, \ldots, \tau_{K}$. Let $\tau$ denote the set of all cut points. To identify the model, we set $\tau_{0}$ equal to $-\infty, \tau_{1}$ equal to zero, and $\tau_{K}$ equal to $\infty$. Before imposing the restrictions, there are $(K+1)$ cut points; after identification, there remain $(K-2)$ to estimate. Given this specification, the marginal probability of observing a particular standard is

$$
\operatorname{Pr}\left(y_{1, i}=k\right)=\Phi\left(\tau_{k}, x_{1, i}^{\prime} \beta_{1}, 1\right)-\Phi\left(\tau_{k-1}, x_{1, i}^{\prime} \beta_{1}, 1\right),
$$

where $\Phi\left(\cdot, \mu, \sigma^{2}\right)$ denotes the cumulative distribution of the normal distribution with location parameter $\mu$ and scale parameter $\sigma^{2}$. The location of the latent utilities with respect to the cut points is what determines the probability of observing certain outcomes.

The second equation is the model for Outcome, which is a dichotomous variable. We assume that

$$
z_{2, i}^{*}=x_{2, i}^{\prime} \beta_{2}+\varepsilon_{2, i},
$$

where $\beta_{2}$ is a $\left(P_{2} \times 1\right)$ column vector of parameters to estimate. The marginal probability that the party alleging discrimination lost the case is

$$
\operatorname{Pr}\left(y_{2, i}=0\right)=\Phi\left(0, x_{2, i}^{\prime} \beta_{2}, 1\right) .
$$

The marginal probability that the party alleging discrimination won the case is this probability subtracted from one. A positive latent utility corresponds to a case win; a negative utility corresponds to a case loss.

If we were willing to assume that the Standard and Outcome choices were independent, we could assume that $\varepsilon_{1, i}$ and $\varepsilon_{2, i}$ were independent and distributed according to a standard normal distribution. This would result in an ordinal probit model (equation (1)) and a dichotomous probit model (equation (3)), which could be estimated equation by equation using the maximum likelihood method and standard software. In this application, however, it makes no substantive sense to assume that the errors are independent. Indeed, we would expect

Markov chain Monte Carlo methods, would be a promising avenue for estimating higherdimensional models. 
some correlation among the errors. We thus assume that the errors follow a bivariate normal distribution:

$$
\varepsilon_{i}=\left[\begin{array}{l}
\varepsilon_{1, i} \\
\varepsilon_{2, i}
\end{array}\right] \sim \mathcal{N}_{2}\left[\left(\begin{array}{l}
0 \\
0
\end{array}\right),\left(\begin{array}{ll}
1 & \rho \\
\rho & 1
\end{array}\right)\right]
$$

The diagonal elements of the variance-covariance matrix are normalized to one to identify the scales on which the latent utilities are measured. The parameter $\rho$ is a correlation parameter that gauges the extent to which the errors are correlated. One could stack equations (1) and (3) to form a seemingly unrelated regression model in the latent utility space.

To compute the joint probability of observing a particular outcome, one would need to integrate the bivariate normal distribution over the correct region. For example,

$$
\operatorname{Pr}\left(y_{1, i}=3, y_{2, i}=1\right)=\int_{\tau_{2}}^{\tau_{3}} \int_{0}^{\infty} \phi_{2}\left(\mu_{i}, \Sigma\right) d z_{2, i} d z_{1, i},
$$

where

$$
\mu_{i}=\left[\begin{array}{l}
x_{1, i}^{\prime} \beta_{1} \\
x_{2, i}^{\prime} \beta_{2}
\end{array}\right] \quad \text { and } \quad \Sigma=\left[\begin{array}{ll}
1 & \rho \\
\rho & 1
\end{array}\right]
$$

and $\phi$ denotes the probability density function of the bivariate normal distribution with mean $\mu_{i}$ and variance-covariance matrix $\Sigma$. The probabilities of all other outcomes are computed similarly.

\section{B.1. Estimation}

We estimate the model using maximum likelihood. The log-likelihood function for the model is

$$
\begin{gathered}
\ln \mathcal{L}\left(\beta_{1}, \beta_{2}, \tau, \rho \mid y_{1, i}, y_{2, i}\right) \\
=\sum_{i=1}^{N} \sum_{k=1}^{K} \square\left(y_{1, i}=k\right)\left\{y_{2, i} \ln \left[\int_{\tau_{k-1}}^{\tau_{k}} \int_{0}^{\infty} \phi_{2}\left(\mu_{i}, \Sigma\right) d z_{2, i} d z_{1, i}\right]\right. \\
\left.+\left(1-y_{2, i}\right) \ln \left[\int_{\tau_{k-1}}^{\tau_{k}} \int_{-\infty}^{0} \phi_{2}\left(\mu_{i}, \Sigma\right) d z_{2, i} d z_{1, i}\right]\right\},
\end{gathered}
$$

where $\mathbb{\square}(\cdot)$ is an indicator function that takes the value of one if $y_{1, i}=k$ and zero otherwise. We maximize the log-likelihood function using the Broyden-FletcherGoldfarb-Shanno algorithm (Nocedal and Wright 1999, pp. 194-201), using the $\mathrm{R}$ (Ihaka and Gentleman 1999) implementation in the optim() function. There are no known analytical methods for computing the rectangular integrals in the likelihood function. We use the simulation method of Genz (1992), which is implemented in the sn library (Azzalini 2002). For problems of modest size 
$(N \approx 450)$, the optimizer takes $2-3$ hours to converge on a dedicated Linux workstation. We use the equation-by-equation maximum likelihood estimates for starting values, which speeds convergence considerably. ${ }^{33}$ To compute the White (1980) standard errors, we sum the matrix of scores by the clustering variable and then use their weighted outer product to compute the variancecovariance matrix of the estimator.

\section{B.2. Interpretation}

To interpret results from the estimate statistical model, we account for parameter uncertainty by drawing parameter values from their (asymptotic) sampling distribution (see King, Tomz, and Wittenberg 2000). The predicted probabilities in Figures 1 and 3 come from equation (2), and those in Figure 4 are from equation (4). The simulation used to account for parameter uncertainty follows the standard approach.

The algorithm used in Figure 3 is a bit more complicated, as it requires us to draw from the conditional distribution $f\left(z_{2, i}^{*} \mid z_{1, i}^{*}\right)$. This distribution is a normal distribution with mean $x_{2, i}^{\prime} \beta_{2}+\rho\left(z_{1, i}^{*}-x_{1, i}^{\prime} \beta_{1}\right)$ and variance $\left(1-\rho^{2}\right)$. To generate the predicted probabilities, we do the following:

1. Draw a vector of parameters from the (asymptotic) sampling distribution. For each Standard, draw $z_{1, i}^{*}$ from a truncated normal distribution with mean of $x_{1, i}^{\prime} \beta_{1}$ and variance of one. For $y_{1, i}=1$, the distribution is truncated above at zero. For $y_{1, i}=2$, the distribution is truncated below at zero and above at $\tau_{2}$. For $y_{1, i}=3$, the distribution is truncated below at $\tau_{2}$.

2. Compute the probability of each Outcome using the conditional distribution above.

3. Repeat the simulation a large number of times.

It is interesting to note that these predicted probabilities do not look normally distributed.

\section{REFERENCES}

Allen, David W., and Diane E. Wall. 1993. Role Orientations and Women State Supreme Court Justices. Judicature 77:156-65.

Atkins, Burton, and Henry Glick. 1976. Environmental and Structural Variables as Determinants of Issues in State Courts of Last Resort. American Journal of Political Science 20:735-48.

Azzalini, Adelchi. 2002. library sn. CRAN: The Comprehensive R Archive Network. http://tango.stat.unipd.it/SN/.

33. We have fitted the model with dispersed starting values, and the algorithm always converges to the same estimate. 
278 / THE JOURNAL OF LEGAL STUdiES / VOLUME 35 (1) / JANUARY 2006

Beck, Phyllis W., and Joanne Alfano Baker. 1993. An Analysis of the Impact of the Pennsylvania Equal Rights Amendment. Widener Journal of Public Law 3:743-98.

Becker, Mary E. 1989. Obscuring the Struggle: Sex Discrimination, Social Security, and Stone, Seidman, Sunstein and Tushnet's Constitutional Law. Columbia Law Review 89:264-89.

Berry, William D., Evan J. Ringquist, Richard C. Fording, and Russell L. Hanson. 1998. Measuring Citizen and Government Ideology in the American States, 1960-93. American Journal of Political Science 42:327-48.

Bowsher, David K. 1998. Cracking the Code of United States v. Virginia. Duke Law Journal 48:305-39.

Brake, Deborah L. 1996. Sex as a Suspect Class. Seton Hall Constitutional Law Journal 6:953-66.

Bright, Stephen B., and Patrick J. Keenan. 1995. Judges and the Politics of Death. Boston University Law Review 75:760-835.

Brown, Barbara A., Thomas I. Emerson, Gail Galk, and Ann E. Freedman. 1971. The Equal Rights Amendment: A Constitutional Basis for Equal Rights for Women. Yale Law Journal 80:871-985.

Burbank, Stephen B., and Barry Friedman, editors. 2002. Judicial Independence at the Crossroads. Thousand Oaks, Cal.: Sage Publications.

Caldeira, Gregory A., John R. Wright, and Christopher J. Zorn. 1999. Sophisticated Voting and Gate-Keeping in the Supreme Court. Journal of Law, Economics, and Organization 15:549-72.

Caminker, Evan H. 1994. Why Must Inferior Courts Obey Superior Court Precedent? Stanford Law Review 46:817-73.

Canon, Bradley C., and Dean Jaros. 1970. External Variables, Institutional Structure and Dissent on State Supreme Courts. Polity 3:175-200.

Case, Mary Anne. 2000. Constitutional Sex Discrimination: The Law as a Quest for Perfect Proxies. Cornell Law Review 85:1447-91.

- 2002. Reflections on Constitutionalizing Women's Equality. California Law Review 90:765-90.

Croly, Steven P. 1995. The Majoritarian Difficulty: Elective Judiciaries and the Rule of Law. University of Chicago Law Review 62:689-791.

Cross, Frank B., and Emerson H. Tiller. 1998. Judicial Partisanship and Obedience to Legal Doctrine: Whistleblowing on the Federal Courts of Appeals. Yale Law Journal 107:2155-75.

Crump, Susan. 1973. An Overview of the Equal Rights Amendment in Texas. Houston Law Review 11:136-67.

Dahl, Robert A. 1957. Decision-Making in a Democracy: The Supreme Court as a National Policymaker. Journal of Public Law 6:279-95.

Daughtrey, Martha Craig. 2000. Women and the Constitution. New York University Law Review 75:1-31. 
Denning, Branon P., and John R. Vile. 2000. Necromancing the Equal Rights Amendment. Constitutional Commentary 17:593-602.

Deutsch, Norman T. 2003. Nguyen v. INS and the Application of Intermediate Scrutiny to Gender Classifications. Pepperdine Law Review 30:185-271.

Dorf, Michael C. 2002. The Paths to Legal Equality. California Law Review 90: 791-812.

Dorsen, Norman, and Susan Deller Ross. 1971. The Necessity of a Constitutional Amendment. Harvard Civil Rights-Civil Liberties Law Review 6:216-24.

Eagle Forum. 2004. Equal Rights Amendment. http://www.eagleforum.org/era.

Emerson, Thomas I. 1971. In Support of the Equal Rights Amendment. Harvard Civil Rights-Civil Liberties Law Review 6:225-33.

Emmert, Craig F. 1992. An Integrated Case-Related Model of Judicial Decision Making: Explaining State Supreme Court Decisions in Judicial Review Cases. Journal of Politics 54:543-52.

Epstein, Lee, and Jack Knight. 1998. The Choices Justices Make. Washington, D.C.: CQ Press.

Epstein, Lee, and Lynn Mather. 2003. Beverly Blair Cook: The Values of Electicism. Pp. 172-92 in The Pioneers of Judicial Behavior, edited by Nancy Maveety. Ann Arbor: University of Michigan Press.

Epstein, Lee, and Thomas G. Walker. 2004. Constitutional Law for a Changing America: Rights, Liberties, and Justice. Washington, D.C.: CQ Press.

Eskridge, William N., Jr., and Nan D. Hunter. 1997. Sexuality, Gender, and the Law. Westbury, N.Y.: Foundation.

Estrich, Susan. 2002. Politics and the Limits of Law: A Musing for Dean Sullivan. California Law Review 90:813-17.

Farber, Daniel A., William N. Eskridge, Jr., and Philip P. Frickey. 2003. Constitutional Law. St Paul, Minn.: West.

Farone, Andrea J. 2000. The Florida Equal Rights Amendment: Raising the Standard Applied to Gender under the Equal Protection Clause of the Florida Constitution. Florida Coastal Law Journal 1:421-63.

Francis, Roberta W. 2001. Reconstituting the Equal Rights Amendment: Policy Implications for Sex Discrimination. Paper presented at the annual meeting of the American Political Science Association, San Francisco.

Freund, Paul A. 1971. The Equal Rights Amendment Is Not the Way. Harvard Civil Rights-Civil Liberties Law Review 6:234-42.

Gammie, Beth. 1989. State ERAs: Problems and Possibilities. University of Illinois Law Review, pp. 1123-59.

Genz, Alan. 1992. Numerical Computation of Multivariate Normal Probabilities. Journal of Computational and Graphical Statistics 1:141-50.

George, Tracey E., and Lee Epstein. 1992. On the Nature of Supreme Court Decision Making. American Political Science Review 86:323-37.

Ginsburg, Ruth Bader. 1978. The Equal Rights Amendment Is the Way. Harvard Women's Law Journal 1:19-26. 
280 / THE JOURAL OF LEGAL STUdiEs / VOLUME 35 (1) / JANUARY 2006

1979. Sexual Equality under the Fourteenth and Equal Rights Amendments. Washington University Law Quarterly, pp. 161-78.

Glick, Henry Robert, and Kenneth N. Vines. 1973. State Court Systems. Englewood Cliffs, N.J.: Prentice Hall.

Goldstein, Leslie Friedman. 1994. Contemporary Cases in Women's Rights. Madison: University of Wisconsin Press.

Greenberg, Jack. 1976. Judicial Process and Social Change. St. Paul, Minn.: West.

Gryski, Gerard S., Eleanor C. Main, and William J. Dixon. 1986. Models of State High Court Decision Making in Sex Discrimination Cases. Journal of Politics 48:143-55.

Gunther, Gerald. 1971. Foreword: In Search of Evolving Doctrine on a Changing Court: A Model for a Newer Equal Protection. Harvard Law Review 86: $1-49$.

Halberstam, Malvina, and Elizabeth F. Defeis. 1994. Women, Law, and Inequality: Rethinking International Human Rights. Cardozo Law Review 16: 153-68.

Hall, Melinda Gann. 1987. Constituent Influence in State Supreme Court: Conceptual Notes and a Case Study. Journal of Politics 49:1117-24.

Harvard Law Review. 1970. Sex Discrimination and Equal Protection: Do We Need a Constitutional Amendment? special issue. 84:1499-1524.

Hirczy de Mino, Wolfgang P. 1997. Does an Equal Rights Amendment Make a Difference? Albany Law Review 60:1581-1612.

Hunter, Nan D. 2001. The Sex Discrimination Argument in Gay Rights Cases. Journal of Law and Policy 9:397-416.

Ihaka, Ross, and Robert Gentleman. 1999. R: A Language for Data Analysis and Graphics. Journal of Graphical and Computational Statistics 5:299-314.

Kaufman, Risa E. 2001. State ERAs in the New Era: Securing Poor Women's Equality by Eliminating Reproductive-Based Discrimination. Harvard Women's Rights Law Journal 24:191-219.

Kay, Herma Hill. 1981. Sex-Based Discrimination. St. Paul, Minn.: West.

. 1988. Text, Cases and Materials on Sex-Based Discrimination. St. Paul, Minn.: West.

- 2004. Ruth Bader Ginsburg, Professor of Law. Columbia Law Review 104:1-20.

Kay, Herma Hill, and Geraldine Sparrow. 2001. Introduction: Workshop on Judging: Does Gender Make a Difference? Wisconsin Women's Law Journal 16:1-13.

King, Gary, Michael Tomz, and Jason Wittenberg. 2000. Making the Most of Statistical Analyses: Improving Interpretation and Presentation. American Journal of Political Science 44:341-55.

Knight, Jack, and Lee Epstein. 1996. The Norm of Stare Decisis. American Journal of Political Science 40:1018-35. 
Kurland, Philip B. 1971. The Equal Rights Amendments: Some Problems of Construction. Harvard Civil Rights-Civil Liberties Law Review 6:243-52.

Langer, Laura. 2004. Multiple Actors and Competing Risks in the Policymaking (Unmaking Game) of Judicial Review. University of Arizona, Department of Political Science.

Linton, Paul Benjamin. 1997. State Equal Rights Amendments: Making a Difference or a Statement. Temple Law Review 70:907-41.

Lukey, Joan A., and Jeffrey A. Smagula. 2000. Do We Still Need a Federal Equal Rights Amendment? Boston Bar Journal 44:10-28.

MacKinnon, Catharine A. 1987. Unthinking ERA Thinking. University of Chicago Law Review 54:759-71.

Mansbridge, Jane J. 1986. Why We Lost the ERA. Chicago: University of Chicago Press.

McCausland, Mary Patrice. 1983. Washington's Equal Rights Amendment and Law against Discrimination. Washington Law Review 58:465-79.

McKelvey, William, and William Zavoina. 1975. A Statistical Model for the Analysis of A Statistical Model for the Analysis of Ordinal Level Dependent Variables. Journal of Mathematical Sociology 4:103-20.

Mezey, Susan Gluck. 1992. In Pursuit of Equality. New York: St. Martin's.

- 2003. Elusive Equality. Boulder, Col.: Lynne Rienner.

Minnesota Law Review. 1973. The Effect of the Equal Rights Amendment on Minnesota Law, special issue. 57:771-805.

Murphy, Walter F. 1964. Elements of Judicial Strategy. Chicago: University of Chicago Press.

National Council of Women's Organizations. 2004. ERA Task Force. http:// ncwo-online.org/pages.cfm? ID $=162$.

Nocedal, Jorge, and Stephen J. Wright. 1999. Numerical Optimization. New York: Springer.

Nussbaum, Martha C. 2000. In Defense of Universal Values. Cambridge: Cambridge University Press.

O’Neill, Kevin Francis. 1993. The Road Not Taken: State Constitutions as an Alternative Source of Protection for Reproductive Rights. New York Law School Journal of Human Rights 11:5-77.

Pinello, Daniel R. 1995. The Impact of Judicial Selection Method on StateSupreme-Court Policy. Westport, Conn.: Greenwood Press.

- 2003. Gay Rights and American Law. Cambridge: Cambridge University Press.

Post, Robert C. 2003. The Supreme Court, 2002 Term: Foreword: Fashioning the Legal Constitution: Culture, Courts, and Law. Harvard Law Review 117: 4-112.

Revesz, Richard L. 1997. Environmental Regulation, Ideology, and the D.C. Circuit. Virginia Law Review 83:1717-72.

Richards, Mark J., and Herbert M. Kritzer. 2002. Jurisprudential Regimes in 
282 / THE JOURNAL OF LEGAL STUdiES / VOLUME 35 (1) / JANUARY 2006

Supreme Court Decision Making. American Political Science Review 96: 305-20.

Schneider, Daniel M. 2001. Empirical Research on Judicial Reasoning: Statutory Interpretation in Federal Tax Cases. New Mexico Law Review 31:325-51.

Schoen, Rodric B. 1978. The Texas Equal Rights Amendment in the Courts1972-1977: A Review of Proposed Principles of Interpretation. Houston Law Review 15:537-630.

Segal, Jeffrey A., Charles M. Cameron, and Donald R. Songer. 1995. Decision Making on the U.S. Courts of Appeals. Pp. 227-50 in Contemplating Courts, edited by Lee Epstein. Washington, D.C.: CQ Press.

Sherry, Suzanna. 1986. Civic Virtue and the Feminine Voice in Constitutional Adjudication. Virginia Law Review 72:543-616.

Sherwin, Elizabeth A. 1984-85. Sex Discrimination and State Constitutions: State Pathways through Federal Roadblocks. New York University Review of Law and Social Change 13:115-47.

Siegel, Reva B. 2001. Text in Contest. University of Pennsylvania Law Review 150:297-351.

Simpson, Reagan W. 1977. A New Look at the Texas Equal Rights Amendment. Texas Law Review 55:323-42.

Soule, Sarah A., and Susan Olzak. 2004. When Do Social Movements Matter? The Politics of Contingency and the Equal Rights Amendment. American Sociological Review 69:473-97.

Spaeth, Harold J. 1999. Expanded United States Supreme Court Judicial Database, 1946-68. Study No. 6557. Ann Arbor, Mich.: Inter-university Consortium for Political and Social Research.

- 2005. The Original United States Supreme Court Judicial Database, 1953-2003 Terms. Lexington, Ky.: Ulmer Project for Research in Law and Judicial Politics.

Stanford Law Review. 1950. Sex, Discrimination, and the Constitution, special issue. 2:691-730.

Stobaugh, Heather L. 2002. The Aftermath of United States v. Virginia. SMU Law Review 55:1755-79.

Strauss, David A. 2001. The Irrelevance of Constitutional Amendments. Harvard Law Review 114:1457-1505.

Sullivan, Kathleen M. 2002. Constitutionalizing Women's Equality. California Law Review 90:735-64.

Sunstein, Cass R. 1996. Foreword: Leaving Things Undecided. Harvard Law Review 110:4-101.

Tabarrok, Alexander, and Eric Helland. 1999. Court Politics: The Political Economy of Tort Awards. Journal of Law and Economics 42:157-87.

Tarr, G. Alan, and M. C. Porter. 1982. Gender Equality and Judicial Federalism. Hastings Constitutional Law Quarterly 9:919-72.

Traut, Carol Ann, and Craig F. Emmert. 1998. Expanding the Integrated Model 
of Judicial Decision Making: The California Justices and Capital Punishment. Journal of Politics 60:1166-80.

Vollers, Tony. 1974. The Equal Rights Amendment: Its Meaning and Its Impact on Missouri Law. Missouri Law Review 39:553-72.

Weinrib, Laura. 2003. Protecting Sex: Sexual Disincentives and Sex Based Discrimination in Nguyen v. INS. Columbia Journal of Gender and Law 12: 222-73.

Wheeler, Stanton, Bliss Cartwright, Robert Kagan, and Lawrence M. Friedman. 1987. Do the "Haves" Come Out Ahead? Winning and Losing in State Supreme Courts, 1870-1970. Law and Society Review 21:403-45.

White, Halbert. 1980. A Heteroskedasticity-Consistent Covariance Matrix Estimator and a Direct Test for Heteroskedasticity. Econometrica 48:817-38.

Wolbrecht, Christina. 2000. The Politics of Women's Rights: Parties, Positions, and Change. Princeton, N.J.: Princeton University Press.

Yale Law Journal. 1978. Courting Reversal: The Supervisory Role of State Supreme Courts, special issue. 87:1191-1218. 